\title{
Front Matter: Volume 7267
}

, "Front Matter: Volume 7267," Proc. SPIE 7267, Smart Materials V, 726701 (21 January 2009); doi: 10.1117/12.823566

SDIE Event: SPIE Smart Materials, Nano- and Micro-Smart Systems, 2008, SPIE. Melbourne, Australia 


\section{PROCEEDINGS OF SPIE}

\section{Smart Materials V}

Nicolas H. Voelcker

Helmut W. Thissen

Editors

10-12 December 2008

Melbourne, Australia

Sponsored and Published by

SPIE

Cosponsored by

RMIT University (Australia) 
The papers included in this volume were part of the technical conference cited on the cover and title page. Papers were selected and subject to review by the editors and conference program committee. Some conference presentations may not be available for publication. The papers published in these proceedings reflect the work and thoughts of the authors and are published herein as submitted. The publisher is not responsible for the validity of the information or for any outcomes resulting from reliance thereon.

Please use the following format to cite material from this book:

Author(s), "Title of Paper," in Smart Materials V, edited by Nicolas H. Voelcker, Helmut W. Thissen, Proceedings of SPIE Vol. 7267 (SPIE, Bellingham, WA, 2008) Article CID Number.

ISSN 0277-786X

ISBN 9780819475190

Published by

SPIE

P.O. Box 10, Bellingham, Washington 98227-0010 USA

Telephone +1 3606763290 (Pacific Time) · Fax +1 3606471445

SPIE.org

Copyright (c) 2008, Society of Photo-Optical Instrumentation Engineers

Copying of material in this book for internal or personal use, or for the internal or personal use of specific clients, beyond the fair use provisions granted by the U.S. Copyright Law is authorized by SPIE subject to payment of copying fees. The Transactional Reporting Service base fee for this volume is $\$ 18.00$ per article (or portion thereof), which should be paid directly to the Copyright Clearance Center (CCC), 222 Rosewood Drive, Danvers, MA 01923. Payment may also be made electronically through CCC Online at copyright.com. Other copying for republication, resale, advertising or promotion, or any form of systematic or multiple reproduction of any material in this book is prohibited except with permission in writing from the publisher. The CCC fee code is 0277-786X/08/\$18.00.

Printed in the United States of America.

Publication of record for individual papers is online in the SPIE Digital Library.

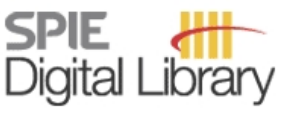

SPIEDigitalLibrary.org

Paper Numbering: Proceedings of SPIE follow an e-First publication model, with papers published first online and then in print and on CD-ROM. Papers are published as they are submitted and meet publication criteria. A unique, consistent, permanent citation identifier (CID) number is assigned to each article at the time of the first publication. Utilization of CIDs allows articles to be fully citable as soon they are published online, and connects the same identifier to all online, print, and electronic versions of the publication. SPIE uses a six-digit CID article numbering system in which:

- The first four digits correspond to the SPIE volume number.

- The last two digits indicate publication order within the volume using a Base 36 numbering system employing both numerals and letters. These two-number sets start with 00, 01, 02, 03, 04 , $05,06,07,08,09,0 A, 0 B \ldots$. OZ, followed by 10-1Z, 20-2Z, etc.

The CID number appears on each page of the manuscript. The complete citation is used on the first page, and an abbreviated version on subsequent pages. Numbers in the index correspond to the last two digits of the six-digit CID number. 


\title{
Contents
}

\author{
vii Conference Committee \\ ix Symposium Sponsor
}

\section{SESSION 1 THIN FILMS}

726702 Low-temperature processing of PZT thin films by $2.45 \mathrm{GHz}$ microwave heating (Invited Paper) [7267-01]

Z. J. Wang, Institute of Metal Research (China); Y. Otsuka, Z. Cao, Tohoku Univ. (Japan); M. W. Zhu, Institute of Metal Research (China); N. Yoshikawa, H. Kokawa, Tohoku Univ. (Japan)

726703 Magnetization switching in multiferroic ceramics by oxygen vacancies [7267-02] T. Sritharan, Nanyang Technological Univ. (Singapore); Y. Li, Nanyang Technological Univ. (Singapore) and Harbin Institute of Technology (China); K. Bai, Institute of High Performance Computing (Singapore)

\section{SESSION 2 PIEZOELECTRICS}

726707 Effect of external vibration on PZT impedance signature of plate structure [7267-06]

Y. Yang, A. Miao, Nanyang Technological Univ. (Singapore)

\section{SESSION 3 ORGANIC-INORGANIC NANOSTRUCTURED COMPOSITES}

7267 OA Silane functionalisation of iron oxide nanoparticles [7267-09]

S. G. Ogden, Flinders Univ. (Australia); D. Lewis, Carl Zeiss Vision (Australia); J. G. Shapter, Flinders Univ. (Australia)

7267 OB Polymer stabilized noble metal colloids for catalytic and biomedical applications [7267-10] S. Mayavan, N. R. Choudhury, N. K. Dutta, Univ. of South Australia (Australia)

7267 OC Preparation of new organic-inorganic composite membranes for water desalination using electrodialysis [7267-11]

C. Klaysom, Univ. of Queensland (Australia); L. Germain, National Polytechnic Institute of Industrial and Chemical Engineering (ENSIACET) (France); S. Burr, The Univ. of Arizona (United States); B. P. Ladewig, L. Wang, J. D. da Costa, G. Q. M. Lu, Univ. of Queensland (Australia)

\section{SESSION 4 ELECTRICAL BEHAVIOR OF POLYMERS}

7267 OD Effect of driving frequency on actuation characteristics of ionic polymer-metal composites [7267-12]

L. Zhang, Y. W. Yang, Nanyang Technological Univ. (Singapore) 
7267 OG Preparation and characterization of multiwalled carbon nanotube (MWCNT)/polymer nanostructured materials (Invited Paper) [7267-15]

K. T. Constantopoulos, C. J. Shearer, J. G. Shapter, N. H. Voelcker, A. V. Ellis, Flinders Univ. (Australia)

$7267 \mathrm{Ol}$ Preparation and characterisation of vertically aligned single-walled carbon nanotube arrays on porous silicon [7267-17]

C. J. Shearer, K. T. Constantopoulos, N. H. Voelcker, J. G. Shapter, A. V. Ellis, Flinders Univ. (Australia)

\section{SESSION 6 SHAPE MEMORY MATERIALS}

7267 OK Shape memory self-deployable structures for solar sails (Invited Paper) [7267-19]

W. Sokolowski, Jet Propulsion Lab., California Institute of Technology (United States); S. Tan, Wright Materials Research (United States); P. Willis, Jet Propulsion Lab. , California Institute of Technology (United States); M. Pryor, ATK Space Systems (United States)

\section{SESSION 7 POROUS SILICON AND ALUMINA}

726700 Designing superhydrophobic surfaces using fluorosilsesquioxane-urethane hybrid and porous silicon gradients [7267-23]

A. G. Kannan, Univ. of South Australia (Australia); S. J. P. Mclnnes, Flinders Univ. (Australia); N. R. Choudhury, N. K. Dutta, Univ. of South Australia (Australia); N. H. Voelcker, Flinders Univ. (Australia)

7267 OP The influence of pore size and oxidizing agent on the energetic properties of porous silicon [7267-24]

A. Plummer, H. Cao, R. Dawson, R. Lowe, J. Shapter, N. H. Voelcker, Flinders Univ. (Australia)

$72670 Q \quad$ Preparation of chemical gradients on porous silicon by a dip coating method [7267-25]

L. Clements, Flinders Univ. (Australia), CSIRO Molecular and Health Technologies (Australia), and CSIRO Food Futures Flagship (Australia); L. Puskar, M. J. Tobin, Australian Synchrotron (Australia); F. Harding, Flinders Univ. (Australia); H. W. Thissen, CSIRO Molecular and Health Technologies (Australia) and CSIRO Food Futures Flagship (Australia);

N. H. Voelcker, Flinders Univ. (Australia) and CSIRO Food Futures Flagship (Australia)

7267 OR An in-situ monitoring system for characterizing porous silicon growth [7267-48]

D. Wyndham, T. James, G. Lim, G. Parish, C. Musca, A. Keating, The Univ. of Western Australia (Australia)

7267 OS Atomic layer deposition of $\mathrm{SIO}_{2}$ on porous alumina membranes: controlling the pore size and transport properties [7267-26]

L. Velleman, Flinders Univ. (Australia); G. Traini, P. J. Evans, A. Atanacio, Australian Nuclear Science and Technology Organisation (Australia); J. G. Shapter, Flinders Univ. (Australia); D. Losic, Univ. of South Australia (Australia) 
7267 OT Pore spanning lipid bilayers on silanised nanoporous alumina membranes [7267-27] A. M. Md Jani, J. Zhou, M. R. Nussio, Flinders Univ. (Australia); D. Losic, Univ. of South Australia (Australia); J. G. Shapter, N. H. Voelcker, Flinders Univ. (Australia)

\section{SESSION 8 SWITCHABLE MATERIALS}

7267 OV Fabrication of electrically switchable photonic crystals with different structures by using a top-cut hexagon prism [7267-29]

X. Sun, X. Tao, Y. Wang, The Hong Kong Polytechnic Univ. (Hong Kong, China)

\section{POSTER SESSION}

$72670 Z$ Application of nanostuctured materials as acid-catalysts in rice straw pyrolysis for bio-oil production [7267-34]

P. T. Dang, H. G. Le, T. C. Dinh, T. V. Hoang, L. H. T. Bui, Y. Hoang, H. K. T. Tran, T. A. Vu, Vietnamese Academy of Science and Technology (Viet Nam)

726711 Magnetic and fluorescence-encoded polystyrene microparticles for cell separation [7267-36]

D. Bradbury, Flinders Univ. (Australia); E. J. Anglin, Flinders Univ. (Australia) and CSIRO Food Futures Flagship (Australia); S. Bailey, P. J. Macardle, Flinders Medical Ctr. (Australia); M. Fenech, CSIRO Human Nutrition (Australia) and CSIRO Food Futures Flagship (Australia); H. Thissen, CSIRO Molecular and Health Technologies (Australia) and CSIRO Food Futures Flagship (Australia); N. H. Voelcker, Flinders Univ. (Australia) and CSIRO Food Futures Flagship (Australia)

726712 Diatom culture media contain extracellular silica nanoparticles which form opalescent films [7267-38]

D. Losic, Univ of South Australia (Australia); J. G. Mitchell, N. H. Voelcker, Flinders Univ. (Australia)

726714 Oriented graphene films for use as high-performance thermal and electrical interconnects [7267-40]

A. Moafi, K. Wong, D. Lau, J. G. Partridge, D. G. McCulloch, RMIT University (Australia)

726717 Study on the intelligent self-healing fiber optic microbend sensors based on the photocurable material [7267-43]

P. Li, Z. Zhao, X. Hong, H. YU, Nanjing Univ. of Aeronautics and Astronautics (China)

726718 Fe-incorporation into mesoporous SBA-15 materials by direct synthesis and post-synthesis [7267-44]

D. T. Phuong, N. T. V. Hoan, L. G. Hy, H. Yen, D. C. Thang, B. T. H. Linh, T. T. K. Hoa, H. V. Thang, V. A. Tuan, Vietnamese Academy of Science and Technology (Viet Nam)

726719 One-step surface modification of poly(dimethylsiloxane) by undecylenic acid [7267-45] J. Zhou, S. J. P. Mclnnes, A. M. Md Jani, A. V. Ellis, N. H. Voelcker, Flinders Univ. (Australia) 
$72671 \mathrm{~A}$ Electrical conducting behavior of hybrid nanocomposites containing polyaniline, carbon nanotube, and carbon black [7267-46]

M. G. Veena, N. M. Renukappa, M. Siddaramaiah, R. D. Sudhaker Samuel, Sri

Jayachamarajendra College of Engineering (India)

Author Index 


\title{
Conference Committee
}

\author{
Symposium Chairs
}

Arnan Mitchell, RMIT University (Australia)

Min Gu, Swinburne University of Technology (Australia)

Conference Chair

Nicolas H. Voelcker, Flinders University (Australia)

Conference Cochair

Helmut W. Thissen, Commonwealth Scientific and Industrial Research Organisation (Australia)

Program Committee

Nicholas L. Abbott, University of Wisconsin/Madison (United States)

Rabah Boukherroub, Institut d'Electronique de Microélectronique et de Nanotechnologie (France)

Namita Roy Choudhury, University of South Australia (Australia)

Jeffrey L. Coffer, Texas Christian University (United States)

Amanda Ellis, Flinders University (Australia)

John J. Gooding, University of New South Wales (Australia)

N. Jayaraman, Indian Institute of Science (India)

Robert Short, University of South Australia (Australia)

Lianzhou Wang, The University of Queensland (Australia)

Session Chairs

1 Thin Films

Nicolas H. Voelcker, Flinders University (Australia)

2 Piezoelectrics

Arnan Mitchell, RMIT University (Australia)

3 Organic-Inorganic Nanostructured Composites

Krasimir Vasilev, University of South Australia (Australia)

4 Electrical Behaviour of Polymers

Namita Roy Choudhury, University of South Australia (Australia)

5 Materials Incorporating Carbon Nanotubes

Krasimir Vasilev, University of South Australia (Australia) 
6 Shape Memory Materials

Nicolas H. Voelcker, Flinders University (Australia)

$7 \quad$ Porous Silicon and Alumina

Adrian J. Keating, The University of Western Australia (Australia)

8 Switchable Materials

Kristina T. Constantopoulos, Flinders University (Australia) 
Cosponsored by:

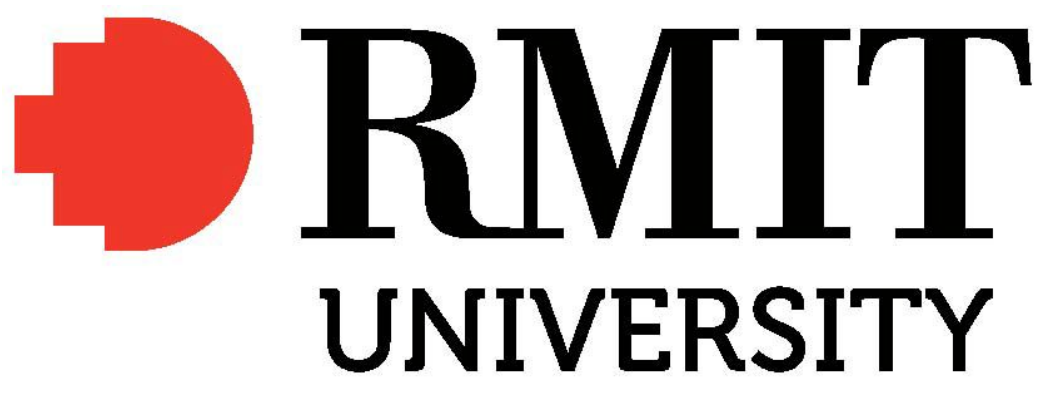


Downloaded From: https://www.spiedigitallibrary.org/conference-proceedings-of-spie on 26 Apr 2023

Terms of Use: https://www.spiedigitallibrary.org/terms-of-use 